\title{
Plasma levels of luteinizing hormone and gonadal maturation of lambari females under different photoperiods
}

\author{
Fernanda Keley Silva Pereira Navarro(1), Rodrigo Diana Navarro(1), Luis David Solis Murgas ${ }^{(2)}$, \\ Marina Apocalypse Nogueira Pereira ${ }^{(2)}$ and Guilherme Crispim Hundley ${ }^{(1)}$
}

\begin{abstract}
(1)Universidade de Brasília, Campus Universitário Darcy Ribeiro, Caixa Postal 4.508, CEP $70910-970$ Brasília, DF. E-mail: fbionavarro@gmail.com, navarrounb@gmail.com, vivendoaquaponia@gmail.com (2)Universidade Federal de Lavras, Departamento de Medicina Veterinária, Setor de Fisiologia e Farmacologia, CEP 37200-00 Lavras, MG. E-mail: Ismurgas@ufla.br, marina_apocalypse@yahoo.com.br
\end{abstract}

\begin{abstract}
The objective of this work was to evaluate the effect of photoperiod on luteinizing hormone (LH) plasma levels and gonadal maturation of lambari females. One hundred and twenty adult lambaris, distributed into 12 aquaria of $20 \mathrm{~L}$ each, were randomly subjected to three different treatments, in a completely randomized design, and four replicates. Treatments were photoperiods in hours of light (L) and darkness (D): T1, 0 L:24 D; T2, 12 L:12 D; T3, 24 L:0 D. After 40 days, fish were subjected to fasting for 24 hours and, then, anesthetized. Immediately after slaughter, fish were weighed, and their gonads and livers were removed and weighed. Ovaries were weighed and immersed in Bouin's fixative solution for 24 hours and, then, kept in 70\% alcohol until processing the material. Subsequently, the oocyte developmental stage was determined. No significant differences were observed between treatments for final weight, ovary weight, gonadosomatic index (GSI), hepatosomatic index (HSI) and LH levels. In all treatments, lambari females showed maturing ovaries with prevalence of vitellogenic oocytes. Photoperiod does not affect the LH levels and ovarian maturation in lambari females.
\end{abstract}

Index terms: Astyanax bimaculatus, native species, gonadosomatic index, hepatosomatic index, oogenesis.

\section{Níveis plasmáticos de hormônio luteinizante e maturação gonadal de fêmeas de lambari sob diferentes fotoperíodos}

\begin{abstract}
Resumo - O objetivo deste trabalho foi avaliar o efeito de fotoperíodo nos níveis plasmáticos do hormônio luteinizante (LH) e na maturação gonadal de fêmeas de lambari. Cento e vinte lambaris adultos, distribuídos em 12 aquários de $20 \mathrm{~L}$ cada um, em delineamento inteiramente casualizado, foram submetidos a três tratamentos e quatro repetições. Os tratamentos foram fotoperíodos, em horas de luz (L) e escuro (E): T1, 0 L:24 E; T2, 12 L:12 E; T3, 24 L:0 E. Após 40 dias, os peixes foram mantidos em jejum de 24 horas e, em seguida, foram anestesiados. Imediatamente após o abate, os peixes foram pesados, e suas gônadas e fígados foram retirados e pesados. Os ovários foram pesados e imersos em solução fixadora de Bouin por 24 horas e, em seguida, foram mantidos em álcool $70 \%$ até o processamento do material. Subsequentemente, o estágio de desenvolvimento dos ovócitos foi determinado. Não foram observadas diferenças significativas entre os tratamentos, quanto a peso final, peso da gônada, índice gonadossomático (IGS), índice hepatossomático (IHS) e níveis de LH. Em todos os tratamentos, as fêmeas de lambari apresentaram ovários em maturação com a prevalência de ovócitos vitelogênicos. O fotoperíodo não influencia os níveis de LH e a maturação ovariana em fêmeas de lambari.

Termos para indexação: Astyanax bimaculatus, espécie nativa, índice gonadossomático, índice hepatossomático, oogênese.
\end{abstract}

\section{Introduction}

Reproductive processes usually show endogenous rhythms triggered by environmental signals, to adjust the reproduction period and the development time of larvae and juveniles to an appropriate environment.

Although numerous environmental factors such as temperature, photoperiod, rainfall, food and pheromones have been implicated as potential influencers of the reproductive activity of different species, the photoperiod probably accounts for the reproductive period of most fish (Sarkar \& Upadhyay, 2011). The photoperiod, an important factor in gonadal maturation of fish, has a direct effect on the hypothalamic-pituitary-gonadal axis of teleost fish, stimulating or inhibiting the production of gonadotropin-releasing hormone $(\mathrm{GnRH})$, pituitary hormones (follicle stimulating hormone - FSH - and 
luteinizing hormone - $\mathrm{LH}$ ), and other hormones that modulate reproduction and maturation of gametes (Amano et al., 2004).

Changes in the light regime are detected by specific receptors, and then transmitted to the brain, the hypothalamus (or directly to the hypothalamus), changing the production and release of GnRH. The GnRH stimulates the release of FSH and LH by the adenohypohysis, which stimulates the release of gonadotropins by the anterior pituitary. FSH stimulates gonadal growth, gametogenesis and the entry of vitellogenin into the oocyte, while LH is important for the final maturation of oocytes and spawning. The influence of gonadotropin on the gonad varies during the maturation process, so that the gonads may be more or less responsive to gonadotropin, and the effect also varies over gonadal development (Navarro \& Navarro, 2012).

The management of environmental conditions can be an excellent tool of manipulation for inducing the gonadal maturation. As an example, the manipulation of photoperiod is being used in aquaculture to change various physiological functions, in different fish species, such as reproduction and gonadal maturation, growth, and spawning season ( $\operatorname{Rad}$ et al., 2006; Guerrero-Tortolero \& Bromage, 2008; Mendonça et al., 2009; Newman et al., 2010; Wilkinson et al., 2010).

The reproduction of many tropical and subtropical species is also influenced by the photoperiod (Sarka \& Upadhyay, 2011). However, studies on photoperiod manipulation effect on the ovarian maturation of native species in Brazil, such as lambari (Astyanax bimacula), are scarce. Lambari is a native fish of Brazil, and belongs to the family Characidae, subfamily Tetragonopterinae. This kind of fish accepts artificial feeding with ease, and has good potential for aquaculture. Its commercial importance is relevant as baits in sport fishing, appetizer and as ornamental fish (Sato et al., 2006). Lambari is omnivorous, and can reach $10.9 \mathrm{~cm}$ and $42 \mathrm{~g}$. Depending on environmental conditions, lambari's spawning can be whole or split (Sato et al., 2006). Further research is necessary to better understand the stimulation process of gonadal maturation and spawning, as well as to improve the quality of gametes, to promote the development of fish farming based on native species in Brazil.
The objective of this work was to evaluate the effect of photoperiod on luteinizing hormone (LH) plasma levels and gonadal maturation of lambari females.

\section{Materials and Methods}

The experiment was conducted in the Laboratory of Physiology and Pharmacology, Department of Veterinary Medicine, at the Universidade Federal de Lavras, (Ufla), Lavras, MG, Brazil, from January $25^{\text {th }}$ to March $7^{\text {th }}, 2010$.

A total of 120 adults of Astyanax bimaculatus, from the aquaculture station of the Universidade Federal de Viçosa, weighing $5.18 \pm 1.8 \mathrm{~g}$, and with $6.5 \pm 0.8 \mathrm{~cm}$ length were used for this experiment. After 15 acclimation days, fish were packaged and distributed into 12 tanks of $20 \mathrm{~L}$ each, in a completely randomized design with three treatments and four replicates. Treatments differed in the simulations of different photoperiods (hours of light:dark) that lasted: T1, 0 light (L):24 dark (D); T2, 12 L:12 D; and T3, $24 \mathrm{~L}: 0 \mathrm{D}$.

Controlled hours of light given during the experiment were adjusted by timers, which automatically switched $20 \mathrm{~W}$ fluorescent lights on and off from the benches, during the specified periods. Light intensity was 1,173 lux, measured by a digital light meter model LDR-208 (Instrutherm, São Paulo, SP, Brazil). During their dark period treatments were isolated to prevent light incidence from other light sources, in order to ensure that the light supply was held during the periods established for each treatment.

The experiment was kept in a closed system of recirculating water. Dissolved oxygen, $\mathrm{pH}$, and temperature were measured daily. Oxygenation levels were maintained with the aid of aerators and measured by a digital oximeter YSI model (Bernauer, Blumenau, $\mathrm{SC}$, Brazil). A multiparameter digital meter was used to measure $\mathrm{pH}$ and temperature .

During the feeding regime, a commercial diet containing $28 \%$ crude protein and $3,100 \mathrm{kcal} \mathrm{kg}^{-1}$ digestible energy Tropical Nutron Hi-Fi, (Nutron Company, Campinas, SP, Brazil) was used. The amount of daily feed was $2 \%$ of body weight and was divided into two daily meals, the first one offered at 9:00 $\mathrm{h}$ and the second at 16:00 h. After 15 min of each meal, boxes were syphoned for the removal of diet remains.

Pesq. agropec. bras., Brasília, v.48, n.8, p.1064-1070, ago. 2013 DOI: 10.1590/S0100-204X2013000800036 
Twelve animals per treatment fasted for 24 hours and were later anesthetized with a benzocaine solution (400 $\mathrm{mg} \mathrm{L}^{-1}$ ). Weight data (ovary, liver, final weight) for each fish were measured using a balance accurate to $0.001 \mathrm{~g}$. Bleeding was performed by cardiac puncture, using $1 \mathrm{~mL}$ syringes containing EDTA at $10 \%$.

To calculate the hepatosomatic index (HSI) we used the formula: $\mathrm{HSI}=100(\mathrm{LW} / \mathrm{BW})$, in which: $\mathrm{LW}$ is the liver weight; and BW is the body weight.

Blood was centrifuged at 5,000 rpm for $10 \mathrm{~min}$, in an centrifuge model 5415C (Eppendorf do Brasil Ltda., São Paulo, SP). Then, the heparinized plasma (supernatant) was removed with a digital pipette. Collected plasma was stored in labeled Eppendorf tubes for subsequent hormone analysis. All plasma material was frozen at $-20^{\circ} \mathrm{C}$ until analysis.

For determining plasma LH, samples were pooled for each treatment, and three individuals were used to comprise $50 \mu \mathrm{L}$ of sample, which was analyzed using an ELISA Kit (LH Dialab/ELISA GbmH, Neudorf, Austria).

After the experiment, samples of lambari female, kept fasting for 24 hours, were taken and anesthetized with benzocaine ( $400 \mathrm{mg} \mathrm{L}^{-1}$ ) for histological analysis. Immediately after slaughter, fish were weighed and had their gonads and total weigh measured on a precision balance $(0.001 \mathrm{~g})$. Then, the ovaries were immersed in Bouin's fixative for 24 hours and kept in $70 \%$ alcohol until resulting material processing, in the Laboratory of Pathology, Department of Veterinary Medicine, at the UFLA. Fixed ovaries were dehydrated in increasing series of alcohol and xylene for paraffin histology. Five-meter-thick sections were obtained in Leica Reichert-Jung microtome Histocut 2040 (ReichertJung Company, West Germany). The preparations were subjected to hematoxylin-eosin staining.

In the light microscope Leica DM500 (Leica Microsystems Company, Buffalo Grove, USA), at 400X magnification, ten fields were examined for ovarian blades of each fish from different treatments. The qualitative stages of gonadal development, through observation of the preparations, were recorded under a microscope. Digital photomicrographs were taken on a Leica DM500 microscope in the Laboratory of Clinical Pathology, of the Faculty of Agronomy and Veterinary Medicine, at Universidade de Brasília (UnB).

The gonadosomatic index (GSI) calculation, which indicates the status of fish gonadal development, was performed using the formula $\mathrm{GSI}=100(\mathrm{GW} / \mathrm{BW})$, in which GW is the gonad weight, and BW is the body weight.

Statistical analysis was performed using the SAS program, and the means were compared by a StudentNewman-Keuls test, at $5 \%$ probability.

\section{Results and Discussion}

During the experimental period, the mean values of temperature $28.67 \pm 0.73^{\circ} \mathrm{C}, \mathrm{pH} \quad 6.65 \pm 0.68$, and dissolved oxygen $5.23 \pm 0.85 \mathrm{mg} \mathrm{L}^{-1}$ were within the range considered acceptable for fish growth, according to Sato et al. (2006).

Female lambaris under different photoperiods showed no significant difference for gonad weight and gonadosomatic index (GSI) (Table 1). Contrasting these results, several studies pointed out the interference of photoperiod on reproductive variables. Studies on photoperiods and long light regimes tend to promote a continuous suppression of gonadal maturation and to redirect the gonadal development of food energy to somatic growth (Ginés et al., 2004). Rad et al. (2006) found that Nile tilapia, kept under continuous light, had a reduced gonadal maturation and lowered values of GSI, followed by increased somatic growth. Salmonid fish in temperature and subjected to long photoperiods or continuous light, also underwent a delay in gonadal development and maturation associated with lower values of GSI (Taranger et al., 2006; Davie et al., 2007). Milla et al. (2009) found lower values of GSI in Perca fluviatilis maintained at constant conditions of photoperiod (12 L:12 D) for three months. However, Miranda et al. (2009) observed that females of

Table 1. Final weight, gonad weight, liver weight, gonadosomatic index (GSI), heptatosomatic index (HSI), and luteinizing hormone (LH), in female lambaris (Astyanax bimaculatus), according to photoperiods ${ }^{(1)}$.

\begin{tabular}{lrrr}
\hline Variable & \multicolumn{3}{c}{ Treatments $^{(2)}$} \\
\cline { 2 - 4 } & \multicolumn{1}{c}{$24 \mathrm{~L}: 0 \mathrm{D}$} & \multicolumn{1}{c}{$12 \mathrm{~L}: 12 \mathrm{D}$} & \multicolumn{1}{c}{$0 \mathrm{~L}: 24 \mathrm{D}$} \\
\hline Final weight $(\mathrm{g})$ & $6,476 \pm 1,747 \mathrm{a}$ & $7,017 \pm 1,281 \mathrm{a}$ & $6,745 \pm 1,783 \mathrm{a}$ \\
Gonad weight $(\mathrm{g})$ & $0,827 \pm 0,425 \mathrm{a}$ & $0,862 \pm 0,189 \mathrm{a}$ & $0,729 \pm 0,502 \mathrm{a}$ \\
Liver weight $(\mathrm{g})$ & $0,038 \pm 0,023 \mathrm{a}$ & $0,052 \pm 0,017 \mathrm{a}$ & $0,039 \pm 0,028 \mathrm{a}$ \\
GSI $\left(\mathrm{mLU} \mathrm{mL}^{-1}\right)$ & $12,710 \pm 6,910 \mathrm{a}$ & $11,620 \pm 2,300 \mathrm{a}$ & $10,830 \pm 4,840 \mathrm{a}$ \\
HSI (mLU mL $\left.\mathrm{mL}^{-1}\right)$ & $0,565 \pm 0,245 \mathrm{a}$ & $0,724 \pm 0,224 \mathrm{a}$ & $0,563 \pm 0,296 \mathrm{a}$ \\
LH $\left(\mathrm{mLU} \mathrm{mL}^{-1}\right)$ & $9,833 \pm 1,649 \mathrm{a}$ & $13,900 \pm 1,632 \mathrm{a}$ & $10,000 \pm 4,656 \mathrm{a}$ \\
\hline
\end{tabular}

${ }^{(1)}$ Means \pm standard error followed by equal letters, on the same line, do not differ significantly, at $5 \%$ probability, by the Student-Newman-Keuls test.

${ }^{(2)}$ Simulations of different photoperiods (light:dark hours). 
Odontesthes bonariensis under short photoperiod (8 L:16 D) showed lower values of GSI in fish exposed to long photoperiod (16 L:8 D).

Manipulating photoperiod had no significant effect on plasma LH (Table 1). Fiszbein et al. (2010) also observed no significant difference in the content of $\beta$-LH in female Cichlasoma dimerus, unlike males which showed lower levels of this hormone under short photoperiods (8 L:16 D). In the study of Skjaeraasen et al. (2004) on Atlantic cod (Gadus morhua L.), males and females, exposed to short photoperiods (8 L:16 D), grew faster steroid levels and showed an earlier onset of the maturation process than under 18 L:6 D. However, Miranda et al. (2009) observed that females of Odontesthes bonariensis under long photoperiods had a significant increase in the expression of GnRH, FSH- $\beta$, LH- $\beta$ and plasma levels of estradiol. Borg et al. (1987) also noted that the dilatation area of cisternae, in the granular endoplasmic reticulum, was larger in cells of pituitary gonadotropin of Gasterosteus aculeatus, under long photoperiod (16 L:8 D), indicating a higher activity of $\beta$-LH secretory system exposed to this light schedule.

The physiological role of LH in teleost fish is still not well understood (Miranda et al., 2009). According to Taranger et al. (2010), LH is important for final oocyte maturation and spawning. In females, LH appears to stimulate the production of $17 \alpha 20 \beta-\mathrm{P}$

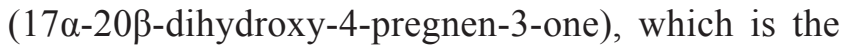
substance that induces oocyte maturation in cells of ovarian follicles (Taranger et al., 2010). Some authors have reported a correlation between increased mRNA transcription of LH- $\beta$ and values associated with the GSI, in non-salmonid fish, in the final stages of oocyte maturation (Luckenbach et al., 2011). In rainbow trout, LH levels increased in the final maturation and spermiation in both sexes (Yaron \& Levavi-Sivan, 2011).

At the end of the experiment, no significant difference was detected in the HSI from lambari females of smelt under different treatments, suggesting that the photoperiod manipulation probably did not influence the energy expenditure for the gonadal development (Table 1). However, in the study of Taranger et al. (2006), male and female Atlantic cod (Gadus morhua) showed higher values of HSI under continuous light (LL) than under natural light regime (LN), which indicates that the LL group invested less energy for reproduction. Ribeiro et al. (2006) also found differences in the HSI, in Steindachnerina insculpta (Characiforme: Curimatidae), which decreased the resting phase in comparison with the maturation phase. The HIS reflects the possible role of hepatic substances in gonadal maturation, especially during the formation of yolk globules, which is shown by the sharp reduction in the values of HIS during advanced maturation in females, and indicates the transfer of hepatic substances to the ovary (Selman \& Wallacc, 1989; Ribeiro et al., 2006). The ultrastructural hepatocyte analysis of female Steindachnerina insculpta, conducted by Ribeiro et al. (2006), showed that when values of HSI were higher, the amount of smooth endoplasmic reticulum were greater, had little glycogen and copious amounts of electro-dense mitochondria. The rise of the HSI and the amount of cytoplasmic organelles are due to increased synthesis of vitellogenin for the formation of oocytes in vitellogenesis.

Macroscopic analysis of Astyanax bimaculatus ovaries showed the same patterns of gonads described for most teleosts (Pereira Filho et al., 2011). The presence of paired, elongate, foliaceous, thick, and bulky organs, was observed in all treatments for A. bimaculatus, as well as in other Astyanax species (Mazzoni et al., 2005). In addition to these results, microscopic examination of gonads indicated a dynamic process of oogenesis, as described by Bazzoli \& Rizzo (1990). Oocytes were classified into four stages, as described by Bazzoli \& Rizzo (1990): 01, young oocytes; 02 , previtellogenic oocytes; 03 , oocytes with cortical vesicles; 04 , oocytes with yolk globules or vitellogenic. Moreover, through histological analysis of gonads, four stages of the female reproductive cycle were established based on the distribution and development of oocytes, according to Melo et al. (2005): 1, home; 2, maturing; and 3, spawning.

In lambari, oocyte development is asynchronous, with the presence of oocytes at different stages of development (Pereira Filho et al., 2011). All treatments of this study showed the same pattern of distribution and development of oocytes (Figure 1). Female lambaris, exposed to different photoperiod regimes, showed an asynchrony of oocyte maturation with a predominance of vitellogenic oocytes, which are rich in yolk granules (Figure 2) and characterized by the emergence and accumulation of yolk globules, in comparison to young and previtellogenic oocytes, which characterized 
by the presence of females with maturing ovaries (Melo et al., 2005). The presence of the same gonadal stage between treatments confirms the similarities in levels of LH, GSI and HSI (Table 1), in animals of different photoperiods, since they are correlated and change depending on the maturity stage. Unlike the results of this study, Milla et al. (2009), by exposing Perca fluviatilis to constant photothermal conditions $\left(20-22^{\circ} \mathrm{C}, 12 \mathrm{~L}: 12 \mathrm{D}\right)$, observed a delay in oogenesis



Figure 1. Lambari (Astyanax bimaculatus) ovary exposed to different light-hour regimes (24 Light:0 Dark, $12 \mathrm{~L}: 12 \mathrm{D}$ and 0 L:24 D), detailing: young oocytes (I); previtellogenic oocytes (II); oocytes with cortical vesicles (III); and oocytes with yolk globules (IV). Hematoxylin-eosin.

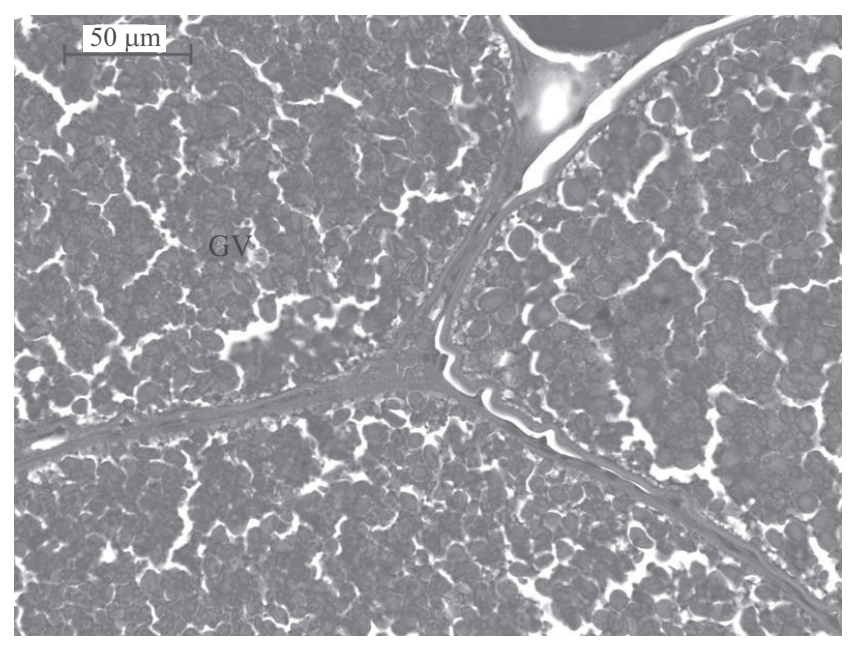

Figure 2. Lambari (Astyanax bimaculatus) ovary exposed to different light-hour regimes (24 Light:0 Dark, 12 L:12 D and 0 L:24 D), detailing: yolk granules (GV) of vitellogenic oocytes. Hematoxylin-eosin. associated with the absence of vitellogenic oocytes, as well as low levels of circulating sex steroids. Miranda et al. (2009) also found ovaries with a predominance of vitellogenic oocytes, in Odontesthes bonariensis exposed to a photoperiod of $16 \mathrm{~L}: 8 \mathrm{D}$. Rad et al. (2006) verified a lower gonadal development, associated with a lower amount of vitellogenic oocytes, in Nile tilapia (Oreochromis niloticus) under a 24 L:0 D regime.

Most studies involving photoperiod and reproduction of fish indicate a relationship between photoperiod and the hypothalamic-pituitary-gonadal axis, reflected by changes in oogenesis and changes in levels of pituitary hormones and steroids for the reproduction.

However, in the present work, the physiological patterns of reproductive axis followed the same trend in all treatments, irrespectively photoperiod. None of the photoperiod regimes were able to stimulate or inhibit the reproductive variables and ovarian maturation in female lambari. This can be explained by the low influence of photoperiod on maturation process of this species, in comparison to other environmental variables, or the use of animals already associated with reproductive failure in the time of animal exposure to different light regimes.

Therefore, besides studying the photoperiod effects on oocytes, further researches are necessary to evaluate the effects of this abiotic factor on gamete quality. These and other information to test the interaction of abiotic factors in fish reproduction can guide new experiments to improve the growing conditions, increase the number of $A$. bimaculatus for fish farming, and thus make production more economically viable.

\section{Conclusion}

Light regimes has no influence on the plasma levels of luteinizing hormone (LH) and ovarian maturation of female lambari (Astyanax bimaculatus).

\section{References}

AMANO, M.; YAMANOME, T.; YAMADA, H.; OKUZAWA, K.; YAMAMORI, K. Effects of photoperiod on gonadotropin-releasing hormone levels in the brain and pituitary of underyearling male barfin flounder. Fisheries Science, v.70, p.812-818, 2004. DOI: 10.1111/j.1444-2906.2004.00874.x.

BAZZOLI, N.; RIZZO, E. A comparative cytological and cytochemical study of the oogenesis in ten Brazilian teleost fish species. European Archives of Biology, v.101, p.339-410, 1990. 
BORG, B.; PEUTE, J.; RESCHKE, M.; VAN DEN HURK, R. Effects of photoperiod and temperature on testes, renal epithelium, and pituitary gonadotropic cells of the threespine stickleback, Gasterosteus aculeatus L. Canadian Journal of Zoology, v.65, p.14-19, 1987. DOI: 10.1139/z87-003.

DAVIE, A.; QUERO, C.M. de; BROMAGE, N.; TREASURER, J.E.; MIGAUD, H. Inhibition of sexual maturation in tank reared haddock (Melanogrammus aeglefinus) through the use of constant light photoperiods. Aquaculture, v.270, p.379-389, 2007. DOI: 10.1016/j.aquaculture.2007.04.052.

FISZBEIN, A.; CÁNEPA, M.; VÁZQUEZ, G.R.; MAGGESE, C.; PANDOLFI, M. Photoperiodic modulation of reproductive physiology and behaviour in the cichlid fish Cichlasoma dimerus. Physiology and Behavior, v.99, p.425-432, 2010. DOI: 10.1016/j.physbeh.2009.11.017.

GINÉS, R.; AFONSO, J.M.; ARGÊLLO, A.; ZAMORANO, M.J.E.; LUIS LÓPEZ, J.L. The effects of long-day photoperiod on growth, body composition and skin colour in immature gilthead sea bream (Sparus aurata L.). Aquaculture Research, v.35, p.1207-1212, 2004. DOI: 10.1111/j.1365-2109.2004.01126 .x.

GUERRERO-TORTOLERO, D.A.; BROMAGE, N. Growth and maturation of Atlantic salmon (Salmo salar) populations with different grilse proportions under natural photoperiod and superimposed nighttime light. Aquaculture, v.285, p.63-66, 2008. DOI: 10.1016/j.aquaculture.2008.07.045.

LUCKENBACH, J.A.; DICKEY, J.T.; SWANSON, P. Follicle-stimulating hormone regulation of ovarian transcripts for steroidogenesis-related proteins and cell survival, growth and differentiation factors in vitro during early secondary oocyte growth in coho salmon. General and Comparative Endocrinology, v.171, p.52-63, 2011. DOI: 10.1016/j. ygcen.2010.12.016.

MAZZONI, R.; MENDONÇA, R.S.; CARAMASCHI, E.P. Reproductive biology of Astyanax janeiroensis (Osteichthyes, Characidae) from the Ubatiba River, Maricá, RJ, Brasil. Brazilian Journal of Biology, v.65, p.643-649, 2005. DOI: 10.1590/ S1519-69842005000400012.

MELO, F.C.S.A. de; MALDONADO, I.R. dos S.C.; BENJAMIN, L. dos A.; MATTA, S.L.P. da. Biologia reprodutiva de fêmeas de lambari-prata (Astyanax scabripinnis) (Characidae, Tetragonopterinae) em tanques de piscicultura. Revista Ceres, v.52, p.811-829, 2005.

MENDONÇA, P.P.; FERREIRA, R.A.; VIDAL JUNIOR, M.V.; ANDRADE, D.R.; SANTOS, M.V.B.; FERREIRA, A.V.; REZENDE, F.P. Influência do fotoperíodo no desenvolvimento de juvenis de tambaqui (Colossoma macropomum). Archivos de Zootecnia, v.58, p.323-331, 2009. DOI: 10.4321/ S0004-05922009000300001.

MILLA, S.; MANDIKI, S.N.M.; HUBERMONT, P.; ROUGEOT, C.; MÉLARD, C.E; KESTEMONT, P. Ovarian steroidogenesis inhibition by constant photothermal conditions is caused by a lack of gonadotropin stimulation in Eurasian perch. General and Comparative Endocrinology, v.163, p.242-250, 2009. DOI: 10.1016/j.ygcen.2009.04.010.
MIRANDA, L.A.; STRUSSMANN, C.A.; SOMOZA, G.M. Effects of light and temperature conditions on the expression of $\mathrm{GnRH}$ and GtH genes and levels of plasma steroids in Odontesthes bonariensis females. Fish Physiology and Biochemistry, v.35, p.101-108, 2009. DOI: 10.1007/s10695-008-9232-3.

NAVARRO, F.K.S.P.; NAVARRO, R.D. Importância do fotoperíodo no crescimento e na reprodução de peixes. Revista Brasileira de Reprodução Animal, v.36, p.94-99, 2012.

NEWMAN, D.M.; JONES, P.L.; INGRAM, B.A. Advanced ovarian development of Murray cod Maccullochella peelii peelii via phase-shifted photoperiod and two temperature regimes. Aquaculture, v.310, p.206-212, 2010. DOI: 10.1016/j. aquaculture.2010.08.024.

PEREIRA FILHO, H.P.; ANDRADE, D.R. de; TONINI, W.C.T; VIDAL JUNIOR, M.V. Biologia reprodutiva de fêmeas de lambari-prata, Astyanax scabripinnis Jenyns, 1842 (Characidae; Tetragonopterinae;Teleostei) em condições de cativeiro. Ciência Animal Brasileira, v.12, p.626-634, 2011. DOI: 10.5216/cab. v12i4.2202.

RAD, F.; BOZAOĞLU, S.; GÖZÜKARA, S.E.; KARAHAN, A.E.; KURT, G. Effects of different long-day photoperiods on somatic growth and gonadal development in Nile tilapia (Oreochromis niloticus L.). Aquaculture, v.255, p.292-300, 2006. DOI: 10.1016/j.aquaculture.2005.11.028.

RIBEIRO, V.M.A.; BAZZOLI, N.; MARIA, T.A.; SANTOS, G.B. Ultrastructural changes in female hepatocytes during ovarian maturation of Steindachnerina insculpta (Pisces: Curimatidae). Brazilian Journal of Biology, v.66, p.957-962, 2006. DOI: 10.1590/S1519-69842006000600002.

SARKAR, A.; UPADHYAY, B. Influence of photoperiod and temperature on reproduction and gonadal maturation in goldfish: Carassius auratus. International Journal of Applied Biology and Pharmaceutical Technology, v.2, p.352-358, 2011.

SATO, Y.; SAMPAIO, E.V.; FENERICH-VERANI, N.; VERANI, J.R. Biologia reprodutiva e reprodução induzida de duas espécies de Characidae (Osteichthyes, Characiformes) da bacia do São Francisco, Minas Gerais, Brasil. Revista Brasileira de Zoologia, v.23, p.267-273, 2006. DOI: 10.1590/S0101-81752006000100021.

SELMAN, K.; WALLACE, R.A. Cellular aspects of oocyte growth in teleosts. Zoological Science, v.6, p.211-231, 1989.

SKJAERAASEN, J.E.; SALVANES, A.G.V.; KARLSEN, O.; DAHLE, R.; NILSEN, T.; NORBERG, B. The effect of photoperiod on sexual maturation, appetite and growth in wild Atlantic cod (Gadus morhua L.). Fish Physiology and Biochemistry, v.30, p.163-174, 2004. DOI: 10.1007/s10695-005-4319-6.

TARANGER, G.L.; AARDAL, L.; HANSEN, T.; KJESBU, O.S. Continuous light delays sexual maturation and increases growth of Atlantic cod (Gadus morhua L.) in sea cages. Journal of Marine Science, v.63, p.365-375, 2006. DOI: 10.1016/j. icesjms.2005.10.014.

TARANGER, G.L.; CARRILLO, M.; SCHULZ, R.W.; FONTAINE, P.; ZANUY, S.; FELIP, A.; WELTZIEN, F.A.; DUFOUR, S.; KARLSEN, O.; NORBERG, B.; ANDERSSON, E.; HANSEN, T. Control of puberty in farmed fish. General and 
Comparative Endocrinology, v.165, p.483-515, 2010. DOI: 10.1016/j.ygcen.2009.05.004.

WILKINSON, R.J.; LONGLAND, R.; WOOLCOTT, H.; PORTER, M.J.R. Effect of elevated winter-spring water temperature on sexual maturation in photoperiod manipulated stocks of rainbow trout (Oncorhynchus mykiss). Aquaculture, v.309, p.236-244, 2010. DOI: 10.1016/j.aquaculture.2010.08.023.
YARON, Z.; LEVAVI-SIVAN, B. Hormonal control of reproduction and growth: endocrine regulation of fish reproduction. In: FARREL, A.P. (Ed.). Encyclopedia of fish physiology: from genome to environment. San Diego: Academic Press, 2011. p.1500-1508. DOI: 10.1016/B978-0-12-3745538.00058-7.

Recebido em 29 de julho de 2011 e aprovado em 10 de maio de 2013 